\title{
PERTUMBUHAN JANGKRIK HITAM (Gryllus mitratus L.) DENGAN PEMBERIAN PAKAN DAUN SAWI (Brassica chinensis L.)
}

\author{
Ratna Prabawati \\ Program Studi Pendidikan Biologi FKIP Universitas Pendidikan Muhammadiyah Sorong \\ Email: ratnaprabawati58@gmail.com
}

\begin{abstract}
ABSTRAK
Penelitian ini bertujuan untuk mengetahui pertumbuhan jangkrik hitam dengan pemberian pakan daun sawi. Penelitian ini merupakan penelitian eksperimen. Sampel penelitian yang digunakan yaitu 30 ekor jangkrik hitam. Pada penelitian ini pengumpulan data dilakukan setiap seminggu sekali dengan cara pengamatan dan pengukuran langsung terhadap sampel yang akan diteliti. Adapun data yang di ambil yakni: 1) berat rata-rata jangkrik hitam (Gryllus mitratus L.), menimbang berat jangkik seluruh sampel. 2) Panjang Rata-rata Jangkrik Hitam (Gryllus mitratus L.), Mengukur panjang jangkrik dari ujung kepala sampai pada bagian belakang jangkrik. 3) Lebar Rata-rata Jangkrik Hitam (Gryllus mitratus L.), mengukur lebar jangkrik pada seluruh sampel. Berdasarkan hasil penelitian ditemukan adanya pertumbuhan yang signifikan pada jangkrik hitam pada pemberian pakan daun sawi. Data pertumbuhan yang diperoleh dari ketiga perlakuan memiliki beberapa kecenderungan. Pertumbuhan panjang $(\mathrm{cm})$, lebar $(\mathrm{cm})$ dan berat (gram) pada perolehan jenis pakan. Kecenderungan pada 7 hari kedua menuju 7 hari ketiga terjadi peningkatan karena terjadi fase pertumbuhan pada jangkrik hitam.

Kata kunci: Pertumbuhan, Jangkrik Hitam(Gryllus mitratus L.) , Pemberiaan Pakan, Daun Sawi (Brassica chinensis L.)
\end{abstract}

\begin{abstract}
This aim of this study was to known the growth black cricket with the chine cabbage food. This was a experiment. The research sample used was 30 black crickets. In this study data colletion is done once a week by direct observation and measurement of the sample to be studied. As for the data to be taken ie : 1)the average weight of a black cricket (Gryllus mitratus L.), weigh the weight of the black cricket throughout the sample. 2) the average length of a black cricket (Gryllus mitratus L.). Measure the length of the black cricket from the tip of the head to the back of the black cricket. 3) the average width of a black cricket (Gryllus mitratus L.), measure cricket width in all samples. Based on the results of the study found a significant growth and black crickets in mustard leaf feeding. Growth data obtained from the treatments have several trends. Growth in length, windth, and weight (grams) in the acquisitas of types of feed. The tendency in the second 7 days to the third 7 days there was an increase due to a growth phase in black crickets.
\end{abstract}

Keywords: Growth,black cricket (Gryllus mitratus L.), feeding, mustard leaf (Brassica chinensis L.)

\section{PENDAHULUAN}

Indonesia sangat kaya dengan sumber daya alam baik flora maupun fauna. Salah satu kekayaan fauna alam yang mempunyai potensi yang besar untuk dikembangkan adalah jangkrik. Jangkrik yang hidup di alam Indonesia sangat didukung oleh iklim dan cuaca. Jangkrik termasuk serangga malam yang umumnya hidup di tanah persawahan, perkebunan, dan di tempat-tempat terlindung lainnya seperti di bawah bebatuan atau reruntuhan dahan-dahan dan daun kering di hutan dan sudah lama dikenal oleh masyarakat. Makanan utama jangkrik adalah dedaunan, umbi-umbian, dan sayur-sayuran yang tumbuh di sawah atau tegalan, di semak-semak atau di hutan-hutan yang merupakan habitatnya untuk berkembangbiak (Novendra, dkk : 2016). Jangkrik berperan sebagai hewan omnivora (pemakan tumbuhan) dan perompak material organik dari tumbuhan dan jamur. Di dalam suatu ekosistem. Pakan jangkrik yang baik untuk peliharaan ialah hijauan, kacang-kacangan, buah-buahan, dan umbi-umbian yang masih muda serta sayur-sayuran. Sayur-sayuran yang masih segar diberikan pada jangkrik disamping dapat memenuhi kebutuhan makanan (Erniwati, 2012). Jangkrik adalah serangga (insecta) dengan subkelas Pterygota, berukuran sedang dengan panjang kurang lebih $3 \mathrm{~cm}$. Dalam kehidupan aslinya, habitat jangkrik hidup di alam bebas seperti sawah, ladang, dan kebun. Konsumsi makanannya yaitu daun-daunan serta biji-bijian yang ditemukan di tempat keberadaannya (Aswindra : 2016). Jangkrik termasuk hewan berdarah dingin yang suhu tubuhnya sangat bergantung pada lingkungan sekitarnya. Bentuk tubuhnya bulat memanjang, mempunyai sepasang sayap dan sepasang antena (sungut). Pakan, sirkulasi udara dan kepadatan merupakan faktor lingkungan yang sangat berpengaruh terhadap pertumbuhan dan perkembangan jangkrik. Dalam peternakan jangkrik pakan utamanya yaitu voor (setrat) dan dedaunan seperti rumput-rumputan, sayur-sayuran, dan tanaman palawija yang masih muda. Umumnya pakan hijauan atau sayur-sayuran yang berair seperti daun singkong, 
daun pepaya, sawi, gambas, daun pisang yang di potong-potong. Rahardjo (2011:11) menyatakan bahwa "jangkrik adalah binatang sejenis serangga, kalau dilihat secara sekilas bentuknya seperti belalang mempunyai sayap dan tidak bisa terbang terlalu jauh. Dalam dunia ini banyak sekali macam-macam jangkrik." Berbagai jenis jangkrik namun yang sering digunakan untuk peternakan biasanya jangkrik pakan burung (Gryllus mitratus L.) dan jangkrik kalung (Gryllus testaceus L.) yang biasanya digunakan untuk bahan kosmetik.

Jangkrik menurut Muhammad (2011:135) menyatakan bahwa "jangkrik diberi makan antara lain: sawi, wortel, jagung muda, kacang tanah, daun singkong, daun papaya, serta ketimun karena kandungan airnya tinggi". Sawi putih merupakan salah satu jenis sayuran yang memiliki kandungan pro vitamin A, asam askorbat, dan serat yang tinggi (Kusuma, 2012). Jangkrik membutuhkan pakan yang cukup untuk pertumbuhan dan perkembangannya. Pertumbuhan sering juga didefinisikan sebagai pertambahan ukuran, berat, dan bertambahnya jumlah sel (Lakitan, 2010). Karmana (2007:21) menyatakan bahwa "Pertumbuhan adalah bertambahnya ukuran, berat, serta jumlah sel yang bersifat tidak kembali pada keadaan semula." Pertumbuhan dipengaruhi oleh kualitas dan kuantitas pakan, dengan pemberian pakan menunjukkan pertambahan bobot rata-rata individu. Tidak hanya bertambahnya bobot namun dengan bertambahnya tinggi merupakan bukti adanya pertumbuhan dan perkembangan.

Informasi yang belum lengkap mengenai jangkrik yang ada di Indonesia, terutama pada masa pertumbuhannya masih sangat terbatas sehingga perlu dilakukan kajian lebih lanjut terhadap ukuran tubuh jangkrik terhadap jenis makanannya agar didapatkan informasi yang lengkap dalam pengembangan dan budidaya jangkrik.

\section{BAHAN DAN METODE}

Dalam penelitian ini penulis menggunakan eksperimen dengan memberikan perlakuan yaitu menggunakan pakan daun sawi (Brassica chinensis L.) pada jangkrik (Gryllus mitratus L.). Jumlah jangkrik hitam (Gryllus mitratus L.) yang akan digunakan yaitu 30 jangkrik hitam (Gryllus mitratus L.). Alat dan bahan yang digunakan dalam penelitian ini ialah: alat: timbangan digital/ manual (Gram), penggaris, alat tulis, kandang jangkrik. Bahan : sawi putih (Brassica chinensis L.), benih Jangkrik hitam (Gryllus mitratus L.) berumur 10 hari, por. Pakan ayam pedaging (makanan pokok dalam peternakan jangkrik hitam). Kemudian prosedur kerja dalam penelitian persiapan: membuat kandang uji sebagai tempat perlakuan, kandang terbuat dari triplek, reng, jaring kawat dengan ukuran panjang $40 \mathrm{~cm}$, tinggi $60 \mathrm{~cm}$, dan lebar $40 \mathrm{~cm}$. Kandang dibuat senyaman mungkin (kandang dibuat seperti pada peternak jangkrik) agar jangkrik tidak mengalami stres. Pada kandang atau kotak A diberi pakan daun sawi (Brassica chinensis L.) dan por pakan ayam pedaging.

Pemeliharaan Jangkrik: pemeliharaan ialah tahapan yang paling utama dalam pembudidayaan jangkrik, hasil optimal itu akan diperoleh apabila pemeliharaan dilakukan dengan baik. Pemberian pakan pada penelitian ini $2 \mathrm{x}$ dalam 1 harinya. Pagi jam 08.00 WIB dan Sore jam 17.00 WIB. Tahap persiapan pakan sayuran daun sawi putih (Brassica chinensis L.) yakni cuci dan tiriskan sayuran. Menimbang sayuran, banyaknya sayuran disesuaikan dengan umur jangkrik kemudian iris sayuran yang sudah ditiriskan lalu di angin-anginkan hingga kira-kira sudah hilang air yang ada pada permukaan daun. Diangin-anginkan bertujuan agar air yang terdapat pada daun dapat hilang atau menetes untuk menghindari pembusukan daun. Memakai alas ketika menganginkan agar daun tidak kotor lagi. Pakan diletakkan di tengah kotak dengan menggunakan alas. Dibuat merata, jangan menggunung. Membuang sisa sayuran yang tidak dimakan sebelum diganti sebaiknya sore hari. Jangkrik tidak membutuhkan air minum karena makanan yang dikonsumsi sudah cukup mengandung banyak air.

Tehnik Pengumpulan Data : dalam penelitian ini pengumpulan data dilakukan setiap seminggu sekali dengan cara pengamatan dan pengukuran langsung terhadap sampel yang akan diteliti. Adapun data yang di ambil yakni: 1) berat rata-rata jangkrik hitam (Gryllus mitratus L.), menimbang berat jangkik seluruh sampel. 2) Panjang Rata-rata Jangkrik Hitam (Gryllus mitratus L.), Mengukur panjang jangkrik dari ujung kepala sampai pada bagian belakang jangkrik. 3) Lebar Rata-rata Jangkrik Hitam (Gryllus mitratus L.), mengukur lebar jangkrik pada seluruh sampel.

\section{HASIL DAN PEMBAHASAN}

Setelah dilakukan penelitian, peneliti mendapatkan data hasil sebagai berikut:

1. Data Panjang Jangkrik Hitam (cm)

Tabel 1. Ringkasan Deskripsi Data Panjang Jangkrik Hitam (cm)

\begin{tabular}{|c|c|c|c|c|c|c|}
\hline $\begin{array}{l}\text { Perhitung } \\
\text { an } \\
\text { Perlakuan }\end{array}$ & $\mathbf{N}$ & $\sum$ & $X$ & $\begin{array}{l}\text { Data } \\
\text { Max }\end{array}$ & $\begin{array}{l}\text { Data } \\
\text { Min }\end{array}$ & $\mathbf{S}$ \\
\hline 7 hari ke 1 & \multirow{3}{*}{$\begin{array}{l}3 \\
0\end{array}$} & $\begin{array}{l}34, \\
6\end{array}$ & $\begin{array}{l}1,1 \\
5\end{array}$ & 1,3 & 0,9 & \multirow{3}{*}{$\begin{array}{l}0,1 \\
6\end{array}$} \\
\hline 7 hari ke 2 & & 43,1 & $\begin{array}{l}1,4 \\
3 \\
\end{array}$ & 1,6 & 1,3 & \\
\hline 7 hari ke 3 & & 53,1 & $\begin{array}{l}1,7 \\
7 \\
\end{array}$ & 2 & 1,5 & \\
\hline $\begin{array}{l}\text { Keteran } \\
\text { Perlaku } \\
\text { diberi pa } \\
\text { Data M } \\
\text { Data } \mathbf{M} \\
\sum_{\mathbf{S}}\end{array}$ & an: & un $\mathrm{s}$ & $\begin{array}{l}: \mathrm{Da} \\
: \mathrm{Da} \\
: \text { Jun } \\
: \text { Sin }\end{array}$ & $\begin{array}{l}\text { Maksi } \\
\text { Minin } \\
\text { lah jan } \\
\text { pangan }\end{array}$ & $\begin{array}{l}\text { Hitam } \\
\text { mum } \\
\text { num } \\
\text { krik hit } \\
\text { baku }\end{array}$ & yang \\
\hline
\end{tabular}


Panjang jangkrik hitam yang diberi pakan daun sawi dapat dideskripsikan, untuk 7 hari pertama diperoleh jumlah panjang jangkrik hitam $34,6 \mathrm{~cm}$, rata-rata panjang jangkrik hitam $1,15 \mathrm{~cm}$, panjang jangkrik hitam maksimum 1,3 cm, dan panjang jangkrik hitam minimum $0,9 \mathrm{~cm}$. Untuk 7 hari kedua diperoleh jumlah panjang jangkrik hitam 43,1 cm, rata-rata panjang jangkrik hitam 1,43 cm, panjang jangkrik hitam maksimum $1,6 \mathrm{~cm}$, dan panjang jangkrik hitam minimum $1,3 \mathrm{~cm}$. Untuk 7 hari ketiga diperoleh jumlah panjang jangkrik hitam 53,1 cm, rata-rata panjang jangkrik hitam $1,77 \mathrm{~cm}$, panjang jangkrik hitam maksimum $2 \mathrm{~cm}$, dan panjang jangkrik hitam minimum $1,5 \mathrm{~cm}$.

Sedangkan diagram garis yang menunjukkan rata-rata panjang jangkrik, panjang jangkrik maksimal, dan panjang jangkrik minimum dapat dilihat pada Gambar 1.

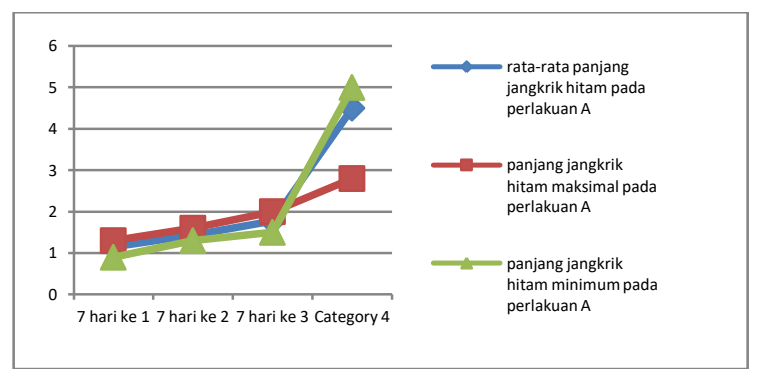

Gambar 1. Diagram Panjang Jangkrik Hitam pada Pemberian Pakan Daun Sawi

2. Data Berat Jangkrik Hitam (gram)

Tabel 2. Ringkasan Deskripsi Data Berat Jangkrik Hitam (gram)

\begin{tabular}{|c|c|c|c|c|c|}
\hline Perhitungan & $\mathrm{N}$ & $\sum$ & $\bar{X}$ & $\begin{array}{l}\text { Data } \\
\text { Max }\end{array}$ & $\begin{array}{l}\text { Data } \\
\text { Min }\end{array}$ \\
\hline Perlakuan & \multirow{4}{*}{30} & & & & \\
\hline 7 hari ke 1 & & 1,99 & 0,067 & 0,067 & 0,06 \\
\hline 7 hari ke 2 & & 4,83 & 0,16 & 0,067 & 0,15 \\
\hline 7 hari ke 3 & & 18,2 & 0,606 & 0,62 & 0,6 \\
\hline \multicolumn{6}{|c|}{$\begin{array}{l}\text { Perlakuan : } \\
\text { diberi pakan daun sawi }\end{array}$} \\
\hline $\begin{array}{l}\text { Data Max } \\
\text { Data Min } \\
\sum\end{array}$ & & $\begin{array}{l}: \mathrm{D} \\
: \mathrm{D} \\
: \mathrm{Ju}\end{array}$ & $\begin{array}{l}\text { Maks } \\
\text { ata Minin } \\
\text { mlah jan }\end{array}$ & $\begin{array}{l}\text { mum } \\
\text { num } \\
\text { skik hit }\end{array}$ & \\
\hline
\end{tabular}

Berat jangkrik hitam yang diberi pakan daun sawi dapat dideskripsikan, untuk 7 hari pertama jumlah berat jangkrik hitam 1,99 gram, rata-rata berat jangkrik hitam 0,067 gram, berat jangkrik hitam maksimum 0,067gram, dan berat jangkrik hitam minimum 0,066 gram. Kemudian 7 hari kedua jumlah berat jangkrik hitam 4,8 gram, rata-rata berat jangkrik hitam 0,16 gram, berat jangkrik hitam maksimum 0,18 gram, dan berat jangkrik hitam minimum 0,15 gram. Sedangkan 7 hari ketiga jumlah berat jangkrik hitam 18,2 gram, rata-rata berat jangkrik hitam 0,606 gram, berat jangkrik hitam maksimum 0,62 gram dan berat jangkrik minimum 0,6 gram.

Ringkasan data pertumbuhan berat selain dapat dideskripsikan melalui tabel 2, data pertumbuhan berat dapat dideskripsikan juga melalui diagram garis, dapat terlihat sebagai berikut:

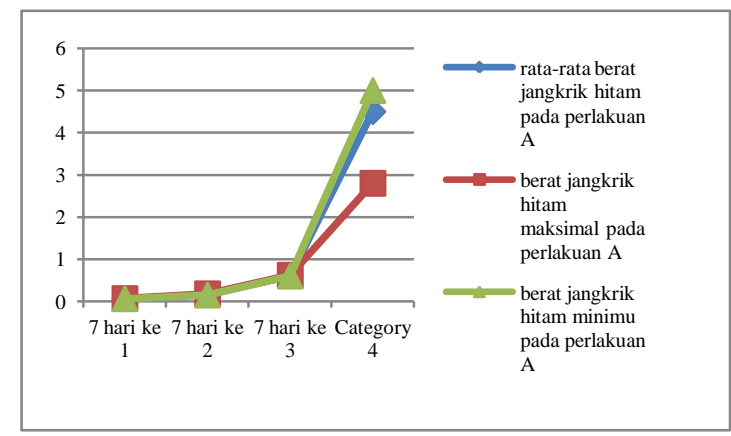

Gambar 2. Diagram Berat Jangkrik Hitam pada Pemberian Pakan Daun Sawi

3. Data Lebar Jangkrik Hitam $(\mathrm{cm})$

Tabel 3. Ringkasan Deskripsi Data Lebar Jangkrik Hitam (cm)

\begin{tabular}{l|l|l|l|l|l}
\hline Perhitungan & \multirow{N}{*}{$\mathrm{N}$} & $\sum$ & $\bar{X}$ & $\begin{array}{l}\text { Data } \\
\text { Max }\end{array}$ & $\begin{array}{l}\text { Data } \\
\text { Min }\end{array}$ \\
\hline Perlakuan & \multirow{3}{*}{ 7 hari ke 1 } & & & & \\
\cline { 4 - 6 } 7 hari ke 2 & \multirow{3}{*}{30,4} & 0,21 & 0,3 & 0,1 \\
\cline { 3 - 6 } 7 hari ke 3 & & 11,8 & 0,39 & 0,5 & 0,2 \\
\cline { 3 - 6 } & & 14,4 & 0,48 & 0,6 & 0,3 \\
\hline Ketrangan:
\end{tabular}

Keterangan:

Perlakuan : Jangkrik Hitam yang

diberi pakan daun sawi

$\begin{array}{ll}\text { Data Max } & \text { : Data Maksimum } \\ \text { Data Min } & \text { : Data Minimum } \\ \Sigma & \text { : Jumlah jangkrik hitam }\end{array}$

Lebar jangkrik hitam yang diberi pakan daun sawi dapat dideskripsikan, untuk 7 hari pertama diperoleh banyaknya jumlah lebar jangkrik hitam 6,4 $\mathrm{cm}$, rata-rata jangkrik hitam $0,21 \mathrm{~cm}$, lebar jangkrik hitam maksimum $0,3 \mathrm{~cm}$, dan lebar jangkrik hitam minimum $0,1 \mathrm{~cm}$. Untuk 7 hari kedua diperoleh banyaknya jumlah lebar jangkrik hitam $11,8 \mathrm{~cm}$, ratarata lebar jangkrik hitam $0,39 \mathrm{~cm}$, lebar jangkrik hitam maksimum $0,5 \mathrm{~cm}$, dan lebar jangkrik hitam minimum $0,2 \mathrm{~cm}$. Untuk 7 hari ketiga diperoleh banyaknya jumlah lebar jangkrik hitam 14,4 cm, rata-rata lebar jangkrik hitam0,48 cm, lebar jangkrik hitam maksimum 0,6 cm, dan lebar jangkrik hitam minimum $0,3 \mathrm{~cm}$.

Data pertumbuhan lebar jangkrik hitam selain dapat dideskripsikan dalam tabel 3 juga dapat dideskripsikan dalam diagram garis, dapat terlihat sebagai berikut: 


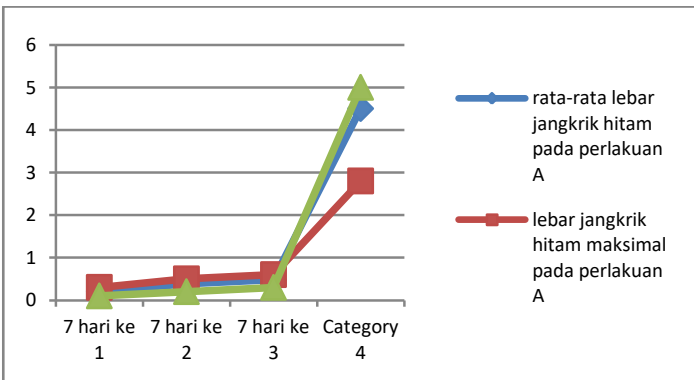

Gambar 3. Diagram Lebar Jangkrik Hitam pada Pemberian Pakan Daun Sawi

Saat penelitian, awal pengambilan bibit yaitu 10 hari dari penetasan dengan jumlah 30 ekor per kandang. Sebelum mengambil bibit jangkrik hitam, peneliti mempersiapkan kandang yang harus diberi lumuran lumpur bagian dalamnya agar suasana kandang seperti di alam. Menunggu keringnya kandang hingga 4 hari. Kemudian baru dimasukkan serasah pisang dan karpet telor untuk bersembunyi jangkrik hitam. Setelah itu baru di masukkan jangkrik hitam ke dalam kandang dengan jumlah 30 ekor. Pada 7 hari pertama pertumbuhan jangkrik hitam belum terlihat pertumbuhannya. Panjangnya $1,2 \mathrm{~cm} \quad(10$ ekor), 0,9 cm (5 ekor), $1,1 \mathrm{~cm}$ (7 ekor), 1,3 cm (8 ekor). Beratnya 0,66 gram (10 ekor), 0,66 gram (10 ekor), dan 0,67 (10 ekor). Kemudian lebar 0,3 cm (11 ekor), 0,2 cm (12 ekor), dan 0,1 cm (7 ekor). Pada 7 hari kedua pertumbuhan jangkrik mulai terlihat namun belum maksimal, panjang 1,6 cm (5 ekor), $1,5 \mathrm{~cm}(8$ ekor), 1,4 cm (10 ekor), dan 1,3 cm (7 ekor). Berat 1,8 gram (10 ekor), 1,5 gram (10 ekor) dan 1,5 gram (10 ekor). Dan lebar 0,5 cm (16 ekor), 0,3 cm (10 ekor), $0,2 \mathrm{~cm}$ (4 ekor). Selanjutnya Pada 7 hari ketiga sudah terlihat pertumbuhan panjang, berat dan lebar jangkrik hitam, panjang 2,0 cm (7 ekor), 1,8 cm (10 ekor), 1,7 $\mathrm{cm}$ (8 ekor), 1,5 cm (5 ekor). Berat 6 gram (10 ekor), 6 gram (10 ekor),dan 6,2 gram (10 ekor). Lebar $0,6 \mathrm{~cm}$ (6 ekor), 0,5 cm (18 ekor), 0,3 cm (6 ekor).

Pada 7 hari ketiga jangkrik sudah terlihat dewasa walaupun belum tumbuh sayap. Jangkrik hitam yang diberi pakan daun sawi pertumbuhannya nampak baik daripada jangkrik hitam yang tidak diberi pakan khusus daun sawi. Hal ini terlihat dari bentuk badan dan pertumbuhan yang begitu nyata. Jangkrik hitam yang diberi pakan daun sawi lebih besar dan panjang. Kandungan nutrisi pada daun sawi dapat dilihat pada tabel berikut:

Tabel 4. Komposisi Gizi Daun Sawi Putih (Brassica chinensis L.)

\begin{tabular}{l|l}
\hline Daun sawi putih & (Brassica chinensis $\mathbf{L})$. \\
\hline Zat gizi & Densitas gizi \\
\hline Vitamin K (mkg) & 449,2 \\
\hline Vitamin A (IU) & 72,7 \\
\hline Vitamin C (mg) & 50,6 \\
\hline Folat (mkg) & 22,0 \\
\hline Mangan (mg) & 16,3 \\
\hline Vitamin E (mg) & 12,0 \\
\hline Triptofon (g) & 10,7 \\
\hline
\end{tabular}

\begin{tabular}{l|l}
\hline Daun sawi putih & (Brassica chinensis L.) \\
\hline Zat gizi & Densitas gizi \\
\hline Serat pangan (g) & 9,6 \\
\hline Kalsium (mg) & 8,9 \\
\hline Kalium (mg) & 6,9 \\
\hline Vitamin B6 (mg) & 6,0 \\
\hline Protein (g) & 5,4 \\
\hline Tembaga (mg) & 5,1 \\
\hline Fosfor (mg) & 4,9 \\
\hline Besi (mg) & 4,7 \\
\hline Vitamin B2 (mg) & 4,5 \\
\hline Magnesium (mg) & 4,5 \\
\hline Vitamin B1 (mg) & 3,4 \\
\hline Vitamin B3 (mg) & 2,6
\end{tabular}

Sumber: Desintya Dewi (2012:44)

Berdasarkan hasil penelitian ditemukan adanya pertumbuhan yang signifikan pada jangkrik hitam pada pemberian pakan daun sawi. Hal ini terbukti dari hasil data yang telah diperoleh selama 3 kali pengukuran. Berdasarkan data pertumbuhan yang diperoleh dari ketiga perlakuan memiliki beberapa kecenderungan. Pertumbuhan panjang $(\mathrm{cm})$, lebar $(\mathrm{cm})$ dan berat (gram) pada perolehan jenis pakan. Sumber pakan jangkrik hitam yang berasal dari daun sawi, memiliki kecenderungan pertumbuhan yang pesat terutama pada 7 hari pertama menuju 7 hari kedua dan 7 hari ketiga selalau terjadi pertambahan panjang, lebar dan berat pada jangkrik hitam yang sangat pesat. Kecenderungan pada 7 hari kedua menuju 7 hari ketiga terjadi peningkatan karena terjadi fase pertumbuhan pada jangkrik hitam. Adanya peningkatan pertumbuhan pada jangkrik hitam tidak lain karena adanya asupan gizi yang diperoleh dari daun sawi.

Sawi merupakan tanaman semusim yang mengandung protein, lemak nabati, karbohidrat, serat, $\mathrm{Ca}, \mathrm{Mg}$, Fe, sodium, vitamin $\mathrm{A}$, dan vitamin $\mathrm{C}$ (Margiyanto, 2008). Dewi (2012:5) mendefinisikan bahwa: "sayuran sawi mengandung Betakaroten, vitamin $\mathrm{B}$-kompleks, vitamin $\mathrm{C}$, vitamin $\mathrm{E}$, serat, fosfor, kalsium, magnesium, asam oksalat, asam nikotinat, karoten, zat besi, glukosinolat, rorifamada dan rorifona (khususnya dalam sawi putih). Menjaga kesehatan tulang, meningkatkan kekebalan tubuh, menggiatkan fungsi organ pencernaan, meningkatkan pembuangan racun dari dalam tubuh dan melindungi serangan penyakit hati." Dengan kandungan vitamin yang begitu melimpah dalam daun sawi banyak manfaat yang di dapat bagi tubuh jangkrik. Salah satu manfaat dari daun sawi yaitu meningkatkan kekebalan tubuh dan membantu jangkrik dalam proses pertumbuhan. Karena sawi juga berfungsi dalam menjaga kesehatan tulang.

Maria (2012) menyatakan bahwa "sawi putih merupakan sayuran daun yang enak rasanya serta banyak mengandung vitamin $\mathrm{A}$ dan vitamin $\mathrm{C}$ serta sedikit vitamin B". Seperti yang kita ketahui bahwa vitamin A selain untuk kesehatan mata vitamin A dan 
$\mathrm{C}$ berfungsi untuk meningkatkan imunitas tubuh bagi jangkrik serta melindungi tubuh terhadap gangguan kesehatan dan infeksi bakteri dan virus. Karena jangkrik mengalami pergantian kulit, vitamin $\mathrm{C}$ sangat bagus dalam memperbaiki sel tubuh dan jaringan kulit yang rusak.

Sawi putih merupakan sayuran yang kaya serat dengan kadar air yang tinggi serta mengandung antioksidan. Karena kaya serat, sawi putih juga dapat melancarkan buang air besar. Daun sawi kandungan airnya lebih tinggi dan bernutrisi sehingga jangkrik hitam yang mengkonsumsi daun sawi lebih gemuk dan besar tetapi lebih pasif dan badannya tidak keset atau tidak padat, jika di pegang jangkrik hitam ini lebih basah. Hal ini disebabkan karena tingginya kandungan air pada sawi sehingga jangkrik hitam nampak lebih basah dibanding jangkrik tanpa pemberian pakan khusus sawi. Hal ini sejalan dengan pedapat (Paimin. 1999) yang menyatakan bahwa umumnya jangkrik menyukai sayuran, dedaunan dan buah-buahan yang mengandung air untuk makananya. Karena satwa ini tidak minum air seperti hewan lain pada umumnya. Makanan yang disukainya salah satunya yaitu sawi. Dengan mengkonsumsi sawi yang mengandung air lebih banyak, kebutuhan air tercukupi dan jangkrik mampu lebih banyak mengkonsumsi sekaligus mencerna pakan dan pada akhirnya jangkrik mengalami pertumbuhan lebih pesat. Hal ini didukung oleh (Mansy, 2002) menyatakan bahwa, pakan siklus udara, dan kepadatan merupakan faktor lingkungan yang sangat berpengaruh terhadap pertumbuhan dan perkembangan jangkrik. Beberapa jenis sayuran yang biasa digunakan sebagai pakan pada pemeliharaan jangkrik adalah sawi, wortel, kangkung, kol, buncis, gambas, bayam, jagung muda, dan daun singkong. Sawi lebih disukai jangkrik karena keadaan fisik dan teksturnya yang lembut dan memiliki kandungan air yang tinggi sehingga pertumbuhan jangkrik yang diberi daun sawi lebih cepat daripada jangkrik yang diberi daun pepaya. Jangkrik membutuhkan pakan yang cukup untuk pertumbuhan dan perkembangannya. Perubahan-perubahan yang utama selama pertumbuhan adalah ukuran dan perbandinganperbandingan tubuh. Pertumbuhan dipengaruhi oleh kualitas dan kuantitas pakan, dengan pemberian pakan menunjukkan pertambahan bobot rata-rata individu. Tidak hanya bertambahnya bobot namun dengan bertambahnya tinggi merupakan bukti adanya pertumbuhan dan perkembangan. Pertumbuhan sering juga didefinisikan sebagai pertambahan ukuran, berat, dan bertambahnya jumlah sel (Lakitan, 2010). Pertumbuhan ini bersifat kuantitatif dan ireversibel (tidak dapat kembali). Pertumbuhan disebabkan oleh bertambahnya jumlah sel-sel penyusun tubuh mahluk hidup tersebut. Penambahan berat, panjang dan tinggi suatu mahluk hidup merupakan bukti-bukti bahwa mahluk hidup itu tumbuh. Bertambahnya berat, panjang dan tinggi merupakan indikator pertumbuhan yang paling mudah untuk diukur yang sifatnya ireversibel. Jadi definisi pertumbuhan jangkrik adalah bertambahnya ukuran, berat, panjang, tinggi serta jumlah sel pada jangkrik yang sifatnya tidak dapat kembali pada keadaan semula yang dipengaruhi oleh kualitas dan kuantitas pakan.

\section{KESIMPULAN}

Berdasarkan data yang diperoleh disimpulkan bahwa pertumbuhan jangkrik hitam yang diberi pakan daun sawi cepat besar dan gemuk tetapi lebih pasif dan badannya tidak keset atau tidak padat.

\section{DAFTAR PUSTAKA}

Aswindra Aji Kurniawan. 2016. Rancang Bangun Aplikasi Web Mobile Manajemen Ternak Jangkrik di UMKM Bos Jangkrik Jogja. Jurnal Teknik Informatika Vol.9 No.1,April 2016.

Dewi, Desintya. Sawi Putih Pengontrol Kolesterol. Surabaya: Stomata. 2012.

Erniwati. Biologi Jangkrik (Orthoptera: Gryllidae) Budidaya dan Peranannya. FAUNA INDONESIA Vol 11 (2) Desember 2012:10-14. 2012.

Karmana, Oman. Cerdas Biologi Untuk Kelas XII.Bandung:GRAFINDO MEDIA PRATAMA. 2007.

Karwono dan Heni Mularsih. Belajar dan Pembelajaran serta Pemanfaatan Sumber Belajar. Ciputat: Cerdas Jaya. 2010.

Kusuma, Maria Erviana. Pengaruh Takaran Pupuk Kandang Kotoran Burung Puyuh Terhadap Pertumbuhan dan Hasil Tanaman Sawi Putih (Brassica junca L.). Jurnal Ilmu Hewani Tropika 1(1):7-11. 2012.

Lakitan, B. Dasar-dasar Fisiologi Tumbuhan. Jakarta: PT Raja Grafindo Persada. 2010.

Mansy, Finito. Performa Jangkrik Kalung (Gryllus bimaculatus) yang Diberi Kombinasi Konsentrat dengan Daun Sawi dan Daun Singkong Selama Masa Pertumbuhan. Skripsi: Fakultas Peternakan Institut Pertanian Bogor. 2002.

Margiyanto, E. 20008.Budidaya Tanaman Sawi. http://zuldesains.wordpress.com. (4 Juli 2020).

Muhammad. Cerdas Budi Daya Jangkrik.Yogyakarta: Pustaka Baru Press. 2011.

Novendra, A.,I.W.Sukanata, dan I W. Budiartha. Analisis Pendapatan Peternakan Dari Usaha Budidaya Ternak Jangkrik. e-Journal FADET UNUD. Universitas Udayana. 2016.

Paimin. Mengatasi Permasalahan Beternak Jangkrik. Cetak 1. Penerbit Swadaya, Jakarta. 1999.

Rahardjo, Dian. Budi Daya Jangkrik dan Peluang Bisnisnya. Yogyakarta:Fortania Media. 2011.

Sudjana. Metode Statistika. Bandung: Tarsito. 2002.

Tim penulis. Pedoman Bertanam Pepaya.Bandung: CV Nuansa Aulia. 2012. 